Article

\title{
Prevalence of the HDI: Alternative consideration of employment factors from 30 OECD countries
}

\author{
Diana Lestari ${ }^{1}$, Dio Caisar Darma ${ }^{2}$, Made Setini ${ }^{3}$, P. Purwadi ${ }^{4 *}$ \\ 1 Department of Economics, Faculty of Economics and Business, Mulawarman University, Samarinda, \\ Indonesia; diana.lestari@feb.unmul.ac.id; ORCID: 0000-0003-0725-3556 \\ 2 Department of Management, Sekolah Tinggi Ilmu Ekonomi Samarinda, Samarinda, Indonesia; \\ diocaisar@stiesam.ac.id; ORCID: 0000-0002-3287-7670 \\ 3 Department of Management, Faculty of Economics and Business, Udayana University, Bali, \\ Indonesia; made.setini@student.unud.ac.id; ORCID: 0000-0001-5041-5835 \\ 4 Department of Management, Faculty of Economics and Business, Mulawarman University, Samarinda, \\ Indonesia; purwadi@feb.unmul.ac.id; ORCID: 0000-0001-5971-6984 \\ * Correspondence: purwadi@feb.unmul.ac.id; Tel.: +6281349463596
}

Received: 21 January 2021; Accepted: 17 March 2021; Published: 20 March 2021

\begin{abstract}
The HDI has played an influential role in the debate on human development for many years. However, no index is perfect in the HDI. It can be argued that the current HDI does not totally reflect human development performance, and thus proper rankings for some countries. Therefore, this article aims to construct a new composite index for the development performance of a sample of 30 organizations for OECD countries by adding a fourth indicator, namely the employment rate to the calculation of HDI. Including employment factors in HDI as a new indicator has not only made the index more comprehensive but also presented a more suitable dimension for assessing the development performance of countries. By considering these factors, it is hoped that people will get a decent income in order to achieve a level of welfare.
\end{abstract}

Keywords: Development; HDI; Employment; OECD Countries; Time-series

JEL codes: O11; O15; E24; C32

\section{Introduction}

During the last twenty years, development has increasingly been defined as human development rather than economic growth, and hence, human development indicators such as life expectancy at birth, school enrolment ratio, literacy rate, gender discrimination, and poverty alleviation have largely been employed to determine and measure the level of development (Wijayanti \& Darma, 2019).

Until now, normalized measures of life expectancy, literacy, educational attainment, and GDP per capita have considered being the main indicators of human development for all nations (for example, Wijaya et al., 2021). Each plays a different role in human development and is unified to give a measure named the Human Development Index (HDI). It should be indicated that HDI does not measure absolute levels of human development, but rather it ranks the countries according to the lowest and highest levels of achievement. In the final phase, the countries are ranked into three groups: low human development (0.000 to 0.499$)$, medium human development (0.500 to 0.799$)$, and high human development (0.800 to 1.000$)$.

HDI has been first calculated in the United Nations Development Program's (UNDP) Human Development Report. Since the first publication of this annual report in 1990, UNDP has been seeking to explore the concept and improve the measurement of global human development. Nonetheless, 
over the last 20 years, there was a considerable amelioration in many aspects of measuring Human Development (HD).

HDI is a simple measure that computes and assigns a single, scalar value to each country of the world based on three components of HD. This measure has radically changed the debate on development and deeply influenced the agenda of both researchers and policymakers around the world since it was implemented. Criticisms and proposed alternatives abound, yet the index has managed to maintain its popularity and simplicity with only minor modifications over the years of 1991, 1994, 1995, 1999, and 2010 (Darma, 2019).

The HDI was developed to measure "the basic concept of human development to enlarge people's choices" (UI Haq, 1995). It was also designed as an alternative to the use of GDP per capita alone as a measure of human prosperity. To these ends, it could be suggested that the HDI has achieved overwhelming success. Since 1990, the HDI has included only a limited number of indicators to keep it simple and manageable. This simple HDI algorithm is still being used today and calculated from regularly available data to produce a meaningful value that can be used to compare and rank countries across the world. Nonetheless, it is still prone to criticisms as it lacks the means to correctly measure and analyze the annual development performance of countries. Smith (1993) has been the first author to suggest and support the significant changes in the HDI while Hopkins (1991), McGillivray (1991), Lüchters \& Menkhoff $(2020)$, and Crafts $(1997,2002)$ have supported the use of the original HDI. On the other hand, there have been many studies in the literature that suggest making radical changes and improvements in the dimensions of the HDI. For example, Srinivasan (1994) and Jordan (2004) have suggested the use of employment or unemployment dimensions in the HDI, while Engineer et al. (2008) calculates the modified indices for OECD countries and compare them with the HDI. Marchante \& Ortega (2006) suggested the use of the 100 minus the rate of long-term unemployment together with 6 other dimensions in an augmented version of the Human Development Index (AHDI). Paul (1996) \& Hicks (1997) have worked on the Gini coefficient and the relevance of inequalities. Ogwang (2000) and Fukuda-Parr (2003) have suggested the gender dimension in their studies. Harttgen \& Klasen (2010) also, suggest the use of the household-based HDI. Neri (2008) has offered the use of the happiness index together with the HDI. Furthermore, Morse (2003) has focused on the "greening of the HDI". Similarly, Costantini \& Monni (2008) has worked on environmental sustainability and its relation to the HDI.

Moreover, Doessel \& Gounder (1994) have highlighted the significance of absolute values rather than rankings in dealing with the HDI dimensions, whereas Panigrahi \& Sivramkrishna (2002), Morse (2003), Osberg \& Sharpe (2003), Cherchye et al. (2008), and Segura \& Moya (2009) have concerned with the problems in HDI rankings. Some critics on HDI have stated that it presents an oversimplified view of HD, and added that a purely economic model focusing on economic growth alone should set the tone on discourse regarding HD. In fact, these critics have attempted to develop their own novel indices or have resulted in the ramification of HDI. However, collecting reliable data continues to be a major obstacle in low-income countries (Harkness, 2004).

Regarding health and longevity, that mortality data are most likely to be missing in countries where mortality is considerably high. According to another critic, both the resources allocated to economic activities and the levels of inequality that may exist within the economy and between various social classes are not taken into account in the HDI (Foster et al., 2005; UI Haq, 1995). In recent years, most critics have taken the issue with assigning equal weights to each of the respective indicators of the index (Mahlberg \& Obersteiner, 2001; Chowdhury \& Squire, 2006).

\section{Literature Review}

The current HDI ignores the inequality in the distribution of HD across populations as well as the efficient use of human resources. This unevenness in the distribution of HD together with the efficiency in the use of human resources might be fully concerned and included in the calculation of HDI by means of adding new indicators to the current HDI such as employment/unemployment rates. HDI has been the combination of two non-income indicators of people's living conditions and one income 
indicator. The employment problem, however, needs to be considered from the long-term development perspective. Thus, this article suggests the employment rate be included in the calculation of the new version of HDI as an additional indicator. This new version of HDI is named the "Unemployment-adjusted Human Development Index" and denoted as HDI-2 (Wolf et al., 2009; Taner et al., 2010).

HDI is not always parallel with GDP per capita, and thus, material welfare level. Some resourcerich countries like oil exporting ones may have a high per capita income level. However, they may place on relatively low ranks of HDI. For example, although countries like Oman and Saudi Arabia have considerably high per capita income levels approaching 23.000 US $\$$ in 2007 , they only managed to attain 56th and 59th HDI ranks among all the nations, respectively (HDR, 2020). This is partly due to the fact that existing wealth is unequally distributed and/or other aspects of development have not been appropriately concerned by the mentioned nations. Countries with high GDP per capita if accompanied by high unemployment rates should be penalized in their HDI rankings unless they can make up for it. Therefore, in order to capture such deficiencies, it would be beneficial to include further indicators in the calculation of HDI. The employment rate emerges as a good indicator for this purpose.

In today's modern world, employment can be recognized as a fundamental human right. It brings personal economic freedom. Providing and implementing strategies for decent and productive work for youth is one of the main targets of the Millennium development goals. Thus, the capacity to develop and meet the job needs of its citizens must be the major goal of every nation in the next decades. Employment can be further considered as a physical need. It constitutes an essential basis for peace, food security, and HD. In this context, securing full employment level can be considered as one of the primary objectives of the nations. Moreover, rising employment levels are also beneficial to foster economic growth and achieve sustainable development.

Furthermore, unemployment is of growing concern because the population has expanded in recent decades even faster than job creation and because a larger percentage of the population, principally women, seek employment more now than at any time in the past. Therefore, economies with high levels of unemployment cannot achieve lasting and sustainable development. To put it differently, economies functioning with full employment level, and thus, high levels of production show radical improvements in terms of HD.

Figure 1. Unemployment-adjusted Human Development Index (HDI-2)

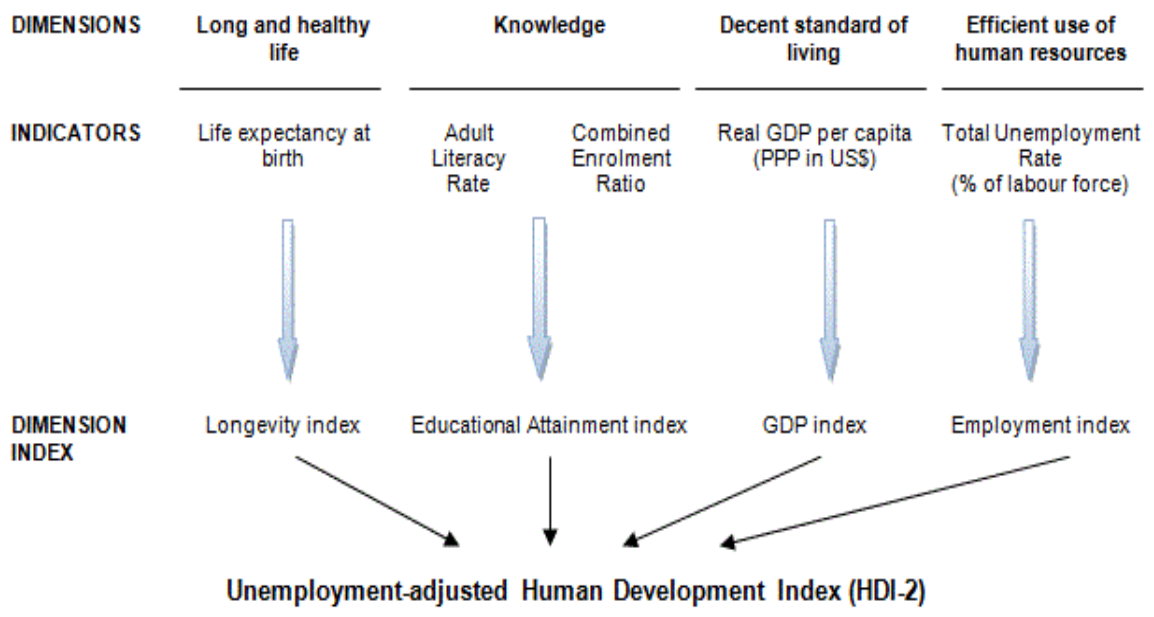

Note. As shown in Figure 1, in addition to the three essential choices of leading a long and healthy life, acquiring knowledge, having access to resources needed for a decent standard of living; efficient use of human resources is included in the measure of HDI-2. That is meant to capture the ability of a nation to utilize the efficient use of human resources. 
Human mobility is one of the major factors influencing employment changes in societies. Thus, migration, both within and beyond borders, has become an increasingly prominent theme in domestic and international debates and is the topic of the Human Development Report in 2019 (HDR, 2020). While immigration pressures are increasing and have become the major concern in most OECD countries, an increase in the share of immigrants in the labor force is estimated to raise temporarily natives' unemployment, over a period of approximately five to ten years (Jean \& Jiménez, 2010). Changes in the share of immigrants in the labor force may have a distributive impact on natives' wages, and a temporary impact on unemployment (Jean et al., 2007).

The unemployment rate is defined as the percentage of the labor force (the employed and unemployed population) aged 15 years and older who are not in paid employment not self-employed but who are available for work and have taken specific steps to seek paid employment or selfemployment (Wijaya et al., 2021). It is a measure of the risk that a person will not have a job if he/she wants to work. Since the risk of unemployment negatively affects human development, in this article HDI-2 is modeled as the average of the trend in the total unemployment rate as a percentage of the labor force. Since the unemployment rate is inversely correlated with HDI, the derived employment rate is preferred to be included in this research.

Although it has not been currently included in the sub-indices of HDI, unemployment is an indicator of social inclusion and quality-of-life through efficient use of human resources. It has an impact on well-being far above the simple loss of income effect (Clark \& Oswald, 1994). Unemployment is viewed as a key factor in causing declines in personal well-being, like deterioration in self-esteem, health, and suicide, and an increased propensity to engage in illegal activities (Machin \& Manning, 1999).

In this article, we argue that it is appropriate to modify the HDI by simply adding an Employment indicator in the index. We denoted this Unemployment-adjusted Human Development Index, HDI-2. OECD countries have been chosen for the analysis since employment/unemployment data are not available or reliable for other country groups in the world.

\section{Methods}

\subsection{Data}

Table 1 lists all the values for HDI-2 and HDI for 2010-2019, respectively. For all years and countries, HDI-2 values are always lower than HDI values. The improvements in HDI values over the years seem to originate from the changes in GDPI since the values of LEI and EI remained almost the same. On the other hand, many OECD countries represent a significant improvement in HDI-2 over the years. This is partly attributable to the inclusion of the employment index in the calculation of HDI.

All of LEI, EI, GDPI, EMPI, and HDI values are obtained from the Human Development Reports (HDR). Then, for each year, the HDI values are compared with the values of HDI-2 by means of a paired $t$-test. The results indicated that the difference between the two indices is statistically significant. Most OECD countries experienced a fall in their employment in 2011-2012 while their GDPIs have been increasing. This has resulted in falls in their HDI-2 for these years. This trend can be further considered as a signal of "jobless growth" for the same OECD countries.

\subsection{Measurements}

The HDI has been based on three sub-indices and four indicators: longevity index (LEI), as measured by life expectancy at birth; educational attainment index, as measured by a combination of adult literacy (two-thirds weight) and combined (i.e. primary, secondary and tertiary) enrolment (onethird weight) ratios (EI); and standard of living, as measured by real GDP index (Purchasing Power Parity in US\$). To calculate the dimensions, UNDP has assigned minimum and maximum values (goalposts) for each underlying sub-indices. Performance in each sub-index is then calculated and expressed as a value between $0-1$. In UNDP's approach, these sub-indices are assigned (equal) weights 
$(\mathrm{x}, \mathrm{y}, \mathrm{z})$ as suggested by Chowdhury \& Squire (2006), Stapleton \& Garrod (2007), and Nguefack-Tsague et al. (2011) as given as below:

$$
H D I=x .(L E I)+y \cdot(E I)+z .(G D P I)
$$

where, $x=y=z=1 / 3$.

Table 1. HDI-2 values, 2010-2019

\begin{tabular}{|c|c|c|c|c|c|c|c|c|c|c|}
\hline & 2010 & 2011 & 2012 & 2013 & 2014 & 2015 & 2016 & 2017 & 2018 & 2019 \\
\hline Iceland & 0.911 & 0.926 & 0.935 & 0.926 & 0.914 & 0.911 & 0.939 & 0.939 & 0.948 & 0.881 \\
\hline Norway & 0.909 & 0.913 & 0.913 & 0.916 & 0.920 & 0.930 & 0.915 & 0.932 & 0.947 & 0.921 \\
\hline Australia & 0.845 & 0.863 & 0.876 & 0.869 & 0.879 & 0.890 & 0.901 & 0.910 & 0.923 & 0.904 \\
\hline Canada & 0.846 & 0.855 & 0.870 & 0.863 & 0.863 & 0.868 & 0.878 & 0.892 & 0.900 & 0.880 \\
\hline Ireland & 0.833 & 0.868 & 0.889 & 0.896 & 0.895 & 0.903 & 0.914 & 0.914 & 0.917 & 0.853 \\
\hline Sweden & 0.843 & 0.880 & 0.896 & 0.905 & 0.910 & 0.899 & 0.893 & 0.879 & 0.896 & 0.836 \\
\hline Switzerland & 0.885 & 0.911 & 0.920 & 0.924 & 0.911 & 0.913 & 0.911 & 0.916 & 0.925 & 0.867 \\
\hline Japan & 0.891 & 0.886 & 0.889 & 0.888 & 0.885 & 0.891 & 0.905 & 0.914 & 0.922 & 0.862 \\
\hline Netherlands & 0.893 & 0.908 & 0.920 & 0.930 & 0.929 & 0.906 & 0.883 & 0.916 & 0.933 & 0.883 \\
\hline France & 0.791 & 0.804 & 0.826 & 0.834 & 0.835 & 0.834 & 0.833 & 0.846 & 0.867 & 0.811 \\
\hline Finland & 0.795 & 0.815 & 0.825 & 0.833 & 0.836 & 0.841 & 0.850 & 0.868 & 0.883 & 0.824 \\
\hline United States & 0.889 & 0.898 & 0.905 & 0.890 & 0.883 & 0.883 & 0.899 & 0.906 & 0.910 & 0.854 \\
\hline Spain & 0.690 & 0.734 & 0.759 & 0.809 & 0.798 & 0.804 & 0.839 & 0.856 & 0.862 & 0.758 \\
\hline Denmark & 0.871 & 0.875 & 0.884 & 0.896 & 0.894 & 0.885 & 0.894 & 0.913 & 0.918 & 0.858 \\
\hline Austria & 0.874 & 0.875 & 0.886 & 0.886 & 0.884 & 0.881 & 0.883 & 0.901 & 0.912 & 0.841 \\
\hline UK & 0.859 & 0.865 & 0.876 & 0.884 & 0.885 & 0.893 & 0.895 & 0.894 & 0.891 & 0.816 \\
\hline Belgium & 0.833 & 0.838 & 0.868 & 0.868 & 0.866 & 0.859 & 0.855 & 0.857 & 0.871 & 0.813 \\
\hline Luxembourg & 0.895 & 0.906 & 0.910 & 0.913 & 0.913 & 0.913 & 0.900 & 0.898 & 0.918 & 0.841 \\
\hline New Zealand & 0.834 & 0.850 & 0.863 & 0.871 & 0.880 & 0.890 & 0.905 & 0.910 & 0.916 & 0.885 \\
\hline Italy & 0.775 & 0.789 & 0.801 & 0.815 & 0.824 & 0.843 & 0.859 & 0.871 & 0.886 & 0.808 \\
\hline Germany & 0.815 & 0.836 & 0.849 & 0.849 & 0.844 & 0.836 & 0.834 & 0.846 & 0.856 & 0.871 \\
\hline Greece & 0.785 & 0.763 & 0.773 & 0.790 & 0.803 & 0.816 & 0.808 & 0.833 & 0.853 & 0.797 \\
\hline Korea Rep. & 0.801 & 0.826 & 0.859 & 0.864 & 0.879 & 0.885 & 0.888 & 0.897 & 0.913 & 0.872 \\
\hline Portugal & 0.836 & 0.849 & 0.860 & 0.871 & 0.859 & 0.849 & 0.834 & 0.827 & 0.831 & 0.753 \\
\hline Czech Rep. & 0.801 & 0.773 & 0.774 & 0.790 & 0.809 & 0.808 & 0.815 & 0.829 & 0.861 & 0.831 \\
\hline Hungary & 0.763 & 0.784 & 0.794 & 0.803 & 0.814 & 0.824 & 0.814 & 0.812 & 0.817 & 0.821 \\
\hline Poland & 0.728 & 0.696 & 0.674 & 0.653 & 0.639 & 0.648 & 0.675 & 0.730 & 0.790 & 0.760 \\
\hline Slovakia & 0.673 & 0.665 & 0.640 & 0.634 & 0.650 & 0.669 & 0.688 & 0.730 & 0.771 & 0.747 \\
\hline Mexico & 0.803 & 0.825 & 0.818 & 0.819 & 0.819 & 0.826 & 0.823 & 0.832 & 0.844 & 0.764 \\
\hline Turkey & 0.715 & 0.709 & 0.728 & 0.694 & 0.684 & 0.684 & 0.693 & 0.708 & 0.745 & 0.641 \\
\hline
\end{tabular}

Source: Authors' calculation.

In our approach, the four indices in the HDI-2 represent a different set of indicators for assessing the aggregate level of $\mathrm{HD}$ with equal weights in the following way: 
where, EMP is the new included index, i.e. the employment index. The resulting indices for each dimension were averaged with equal weights $(k, m, n, p)$ of $1 / 4$, and therefore, the HDI-2 calculated likewise as a simple average of the sub-indices via basic algebra for each OECD country as shown in Table 1. These four sub-indices address conceptually different aspects of HD, which although correlated do not predetermine one another.

Equal weights allow easy comparison over time and across countries. The assessment of change in HDI-2 over the years (2010-2019) for all OECD countries is tabulated in Table 1. From HDI-2 values, comparisons of achievements between countries at a given year or for a particular country for different periods can also be made.

The data have shown that the total unemployment rate and HDI-2 are inversely correlated. Therefore, the employment rate is preferred instead. Performance in employment is expressed as a value between 0 and 1 . The following general formula is constructed by scaling directly from the total unemployment rate as (\%) of the labor force:

Scaled Employment Index $(E I)=1-[(20-$ Actual Unemployment Rate) $/(20)]$

Where, Scaled Employment Index $(\mathrm{EI})=1-$ [(Maximum Unemployment rate goalpost - Actual Unemployment Rate at year i) / Maximum Unemployment rate goalpost - Minimum Unemployment Rate goalpost)].

It should be noted that this formula reduces to (max-value)/max when the min is set to 0 . The choice of goalposts is the same over the years. That is, maximum and minimum goalposts are taken as 20 and 0 , respectively. This scaling technique is used in many indices of social and economic wellbeing. Increases in the value correspond to decreases in the scaled value. In both cases, the range of values is $0-1$, and 0 corresponds to the lowest level of employment, and 1 corresponds to the highest.

\section{Empirical Results}

Except for 2019, there is a high correlation between HDI rankings and HDI-2 rankings as tabulated in Table 2. The behavior of HDI against HDI-2 for 2018 is displayed in Figure 2. The decrease in 2019 shows that the rankings are generally not in the same direction and there are important changes in ranks. On the other hand, the results for other years showed that the difference between the two indices is statistically significant.

Table 2. Paired t-test and Pearson Correlation

\begin{tabular}{lcccccccccc}
\hline & $\mathbf{2 0 1 0}$ & $\mathbf{2 0 1 1}$ & $\mathbf{2 0 1 2}$ & $\mathbf{2 0 1 3}$ & $\mathbf{2 0 1 4}$ & $\mathbf{2 0 1 5}$ & $\mathbf{2 0 1 6}$ & $\mathbf{2 0 1 7}$ & $\mathbf{2 0 1 8}$ & $\mathbf{2 0 1 9}$ \\
\hline $\mathrm{t}$ & -7.428 & -7.149 & -6.116 & -6.430 & -7.045 & 8.165 & -9.243 & 10.699 & 11.973 & -5.946 \\
$\mathrm{t}$-Sig. (2-tailed) & 0.000 & 0.000 & 0.000 & 0.000 & 0.000 & 0.000 & 0.000 & 0.000 & 0.000 & 0.000 \\
Pearson & 0.710 & 0.715 & 0.749 & 0.785 & 0.771 & 0.814 & 0.808 & 0.809 & 0.864 & 0.553 \\
Sig. (2-tailed) & 0.000 & 0.000 & 0.000 & 0.000 & 0.000 & 0.000 & 0.000 & 0.000 & 0.000 & 0.000 \\
\hline
\end{tabular}

Source: Authors' calculation.

As the main function of the HDI is the annual ranking of countries. Table 3 and Table 4 list all the ranks for HDI and HDI-2 for 2010-2019, respectively. The rankings each year should reflect proper and definite results so that they can serve primarily as a policy instrument (particularly in developed countries).

According to HDI-2, Norway has always been ranked among the top 4 countries. The only the Republic of Korea has experienced a continuous rise in HDI-2 ranking throughout the analysis period due to the structure of its economy. It is observed that the Netherlands has experienced a drastic fall in rank in 2016-2017 after being ranked as the 1st in 2013 and 2014. This sharp decline is due to the variations in its unemployment rate. On the other hand, significant advances in the ranks of Australia, 
Ireland, Italy, New Zealand, and Spain is observed until 2019. The ranks of some developing countries such as Poland, Slovakia, and Turkey remained almost the same. These countries often act like outliers. Likewise, no significant rank changes are observed for some countries such as Belgium, France, and Greece.

Figure 2. HDI 2019 versus HDI-2 2019 for OECD countries

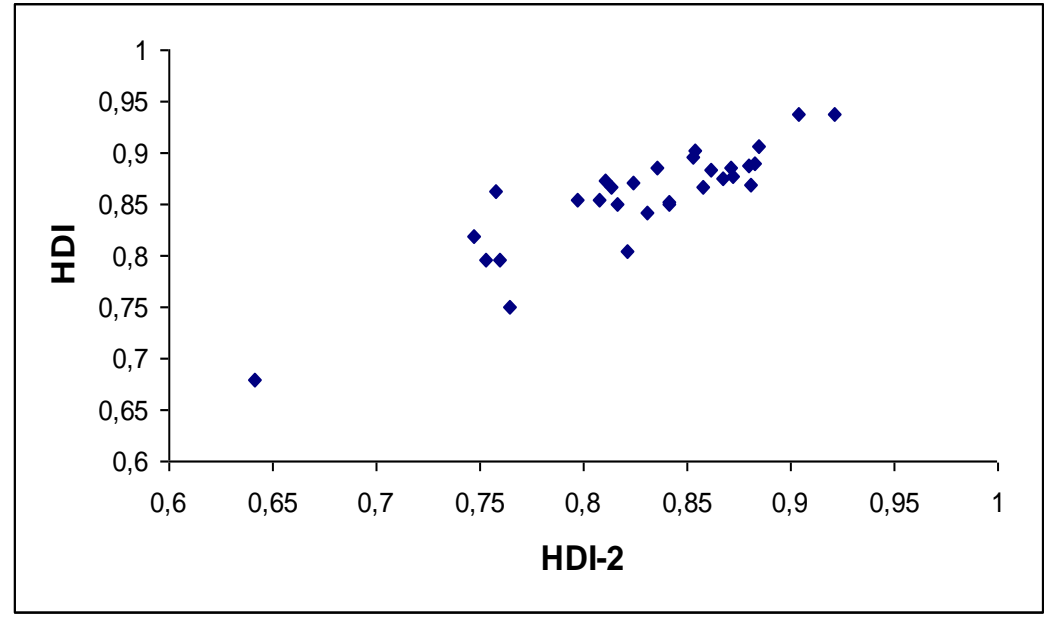

Source: Authors' calculation.

Table 3. Ranks of OECD countries as for HDI

\begin{tabular}{|c|c|c|c|c|c|c|c|c|c|c|}
\hline & 2010 & 2011 & 2012 & 2013 & 2014 & 2015 & 2016 & 2017 & 2018 & 2019 \\
\hline Iceland & 5 & 7 & 7 & 2 & 7 & 2 & 2 & 1 & 3 & 15 \\
\hline Norway & 2 & 1 & 1 & 1 & 1 & 1 & 1 & 1 & 1 & 1 \\
\hline Australia & 4 & 2 & 4 & 4 & 3 & 3 & 3 & 3 & 2 & 2 \\
\hline Canada & 1 & 3 & 3 & 6 & 4 & 4 & 6 & 4 & 4 & 7 \\
\hline Ireland & 18 & 18 & 16 & 14 & 10 & 8 & 4 & 5 & 5 & 5 \\
\hline Sweden & 6 & 3 & 2 & 3 & 2 & 4 & 5 & 6 & 7 & 8 \\
\hline Switzerland & 13 & 11 & 11 & 10 & 10 & 7 & 9 & 7 & 9 & 12 \\
\hline Japan & 9 & 9 & 9 & 9 & 9 & 11 & 7 & 8 & 10 & 10 \\
\hline Netherlands & 8 & 8 & 8 & 5 & 5 & 11 & 10 & 9 & 6 & 6 \\
\hline France & 12 & 12 & 11 & 17 & 18 & 16 & 16 & 10 & 8 & 13 \\
\hline Finland & 11 & 10 & 10 & 12 & 13 & 13 & 11 & 10 & 12 & 14 \\
\hline United St. & 3 & 6 & 4 & 8 & 8 & 10 & 8 & 12 & 13 & 4 \\
\hline Spain & 21 & 21 & 20 & 19 & 20 & 21 & 19 & 13 & 15 & 18 \\
\hline Denmark & 14 & 15 & 15 & 11 & 16 & 13 & 15 & 13 & 16 & 17 \\
\hline Austria & 16 & 15 & 14 & 16 & 14 & 17 & 14 & 15 & 14 & 22 \\
\hline UK & 10 & 14 & 11 & 12 & 10 & 15 & 17 & 16 & 20 & 23 \\
\hline Belgium & 7 & 5 & 4 & 8 & 5 & 9 & 12 & 17 & 17 & 16 \\
\hline Luxembourg & 17 & 12 & 16 & 14 & 15 & 5 & 13 & 18 & 11 & 21 \\
\hline New Zealand & 20 & 19 & 19 & 20 & 18 & 19 & 20 & 19 & 19 & 3 \\
\hline Italy & 19 & 20 & 20 & 21 & 21 & 18 & 17 & 20 & 18 & 20 \\
\hline Germany & 15 & 15 & 16 & 18 & 19 & 20 & 21 & 21 & 21 & 8 \\
\hline Greece & 22 & 22 & 22 & 23 & 22 & 22 & 22 & 22 & 22 & 19 \\
\hline
\end{tabular}




\begin{tabular}{lllllllllll} 
Korea Rep. & 24 & 23 & 23 & 24 & 24 & 24 & 23 & 23 & 23 & 11 \\
Portugal & 23 & 24 & 24 & 22 & 23 & 23 & 24 & 24 & 24 & 27 \\
Czech Rep. & 25 & 25 & 24 & 25 & 25 & 25 & 25 & 25 & 25 & 24 \\
Hungary & 27 & 26 & 26 & 27 & 27 & 26 & 26 & 26 & 28 & 26 \\
Poland & 28 & 27 & 28 & 26 & 26 & 27 & 27 & 27 & 26 & 27 \\
Slovakia & 26 & 21 & 27 & 28 & 28 & 28 & 28 & 28 & 27 & 25 \\
Mexico & 29 & 28 & 29 & 29 & 29 & 29 & 29 & 29 & 29 & 29 \\
Turkey & 30 & 29 & 30 & 30 & 30 & 30 & 30 & 30 & 30 & 30 \\
\hline
\end{tabular}

Source: Authors' calculation.

Comparing the rankings of nations given by HDI and HDI-2 gives us a basis for assessing whether the added employment information matters. As shown in Table 5, inclusion of employment rate in HDI calculations has resulted in crucial increases in the ranks of the Republic of Korea, Denmark, Luxembourg, and Switzerland for all years. These OECD countries have made clear, distinct, evident, and concrete amelioration in the context of HD. The inclusion of the employment rate in HDI-2 had no particular effect on the ranks of Turkey, Slovakia, and Poland.

Table 4. Ranks of OECD countries as for HDI-2

\begin{tabular}{|c|c|c|c|c|c|c|c|c|c|c|}
\hline & 2010 & 2011 & 2012 & 2013 & 2014 & 2015 & 2016 & 2017 & 2018 & 2019 \\
\hline Iceland & 1 & 1 & 1 & 2 & 3 & 4 & 1 & 1 & 1 & 6 \\
\hline Norway & 2 & 2 & 4 & 4 & 2 & 1 & 2 & 2 & 2 & 1 \\
\hline Australia & 12 & 13 & 12 & 15 & 14 & 10 & 7 & 8 & 5 & 11 \\
\hline Canada & 11 & 14 & 14 & 18 & 17 & 16 & 16 & 15 & 14 & 3 \\
\hline Ireland & 16 & 11 & 8 & 7 & 7 & 6 & 3 & 5 & 9 & 18 \\
\hline Sweden & 13 & 8 & 7 & 6 & 6 & 7 & 12 & 16 & 15 & 19 \\
\hline Switzerland & 7 & 3 & 2 & 3 & 5 & 2 & 4 & 3 & 4 & 5 \\
\hline Japan & 5 & 7 & 8 & 10 & 9 & 9 & 5 & 6 & 6 & 12 \\
\hline Netherlands & 4 & 4 & 2 & 1 & 1 & 5 & 14 & 4 & 3 & 2 \\
\hline France & 23 & 22 & 20 & 20 & 21 & 22 & 23 & 21 & 20 & 24 \\
\hline Finland & 22 & 21 & 21 & 21 & 20 & 20 & 19 & 18 & 18 & 20 \\
\hline United St. & 6 & 6 & 6 & 9 & 12 & 14 & 9 & 10 & 13 & 15 \\
\hline Spain & 29 & 27 & 27 & 24 & 27 & 27 & 20 & 20 & 21 & 29 \\
\hline Denmark & 9 & 9 & 11 & 7 & 8 & 12 & 11 & 7 & 7 & 7 \\
\hline Austria & 8 & 9 & 10 & 11 & 11 & 15 & 14 & 11 & 12 & 9 \\
\hline UK & 10 & 12 & 12 & 12 & 9 & 8 & 10 & 14 & 16 & 17 \\
\hline Belgium & 16 & 17 & 15 & 16 & 16 & 17 & 18 & 19 & 19 & 22 \\
\hline Luxembourg & 3 & 5 & 5 & 5 & 4 & 2 & 8 & 12 & 7 & 4 \\
\hline New Zealand & 15 & 15 & 16 & 13 & 13 & 10 & 5 & 9 & 10 & 13 \\
\hline Italy & 25 & 23 & 23 & 23 & 22 & 19 & 17 & 17 & 17 & 23 \\
\hline Germany & 18 & 18 & 19 & 19 & 19 & 21 & 20 & 22 & 23 & 10 \\
\hline Greece & 24 & 26 & 26 & 26 & 26 & 25 & 27 & 23 & 24 & 25 \\
\hline Korea Rep. & 20 & 19 & 18 & 17 & 14 & 12 & 13 & 13 & 11 & 8 \\
\hline Portugal & 14 & 16 & 17 & 13 & 18 & 18 & 20 & 26 & 26 & 26 \\
\hline
\end{tabular}




\begin{tabular}{lllllllllll} 
Czech Rep. & 20 & 25 & 25 & 26 & 25 & 26 & 25 & 25 & 22 & 16 \\
Hungary & 26 & 24 & 24 & 25 & 24 & 24 & 26 & 27 & 27 & 14 \\
Poland & 27 & 29 & 29 & 29 & 30 & 30 & 30 & 28 & 28 & 27 \\
Slovakia & 30 & 31 & 30 & 30 & 29 & 29 & 29 & 29 & 29 & 28 \\
Mexico & 19 & 20 & 22 & 22 & 23 & 23 & 24 & 24 & 25 & 21 \\
Turkey & 28 & 28 & 28 & 28 & 28 & 28 & 28 & 30 & 30 & 30 \\
\hline
\end{tabular}

Source: Authors' calculation.

Additionally, employment negatively affected the HDI values of some OECD countries, especially Canada, France, Sweden, Finland, and Spain. The falls in the ranks of these countries was crucial. These countries are among the ones experiencing net inflows of migrants since their GDP per capita has had an increasing trend. Therefore, they should take precautions to prevent their natives' unemployment problems, control immigration, make adjustments, and implement new policies about the immigrants' integration into the host country labor market. As these adjustments may depend on country-specific factors, they must first concern with the influence of immigrants on the wage-setting mechanism and create economic opportunities for the natives.

Table 5. Differences in HDI rankings (HDI-2 rank less HDI rank)

\begin{tabular}{|c|c|c|c|c|c|c|c|c|c|c|}
\hline & 2010 & 2011 & 2012 & 2013 & 2014 & 2015 & 2016 & 2017 & 2018 & 2019 \\
\hline Iceland & -4 & -6 & -6 & 0 & -4 & 2 & -1 & 0 & -2 & -9 \\
\hline Norway & 0 & 1 & 3 & 3 & 1 & 0 & 1 & 1 & 1 & 0 \\
\hline Australia & 8 & 11 & 8 & 11 & 11 & 7 & 4 & 5 & 3 & 9 \\
\hline Canada & 10 & 11 & 11 & 12 & 13 & 12 & 10 & 11 & 10 & -4 \\
\hline Ireland & -2 & -7 & -8 & -7 & -3 & -2 & -1 & 0 & 4 & 13 \\
\hline Sweden & 7 & 5 & 5 & 3 & 4 & 3 & 7 & 10 & 8 & 11 \\
\hline Switzerland & -6 & -8 & -9 & -7 & -5 & -5 & -5 & -4 & -5 & -7 \\
\hline Japan & -4 & -2 & -1 & 1 & 0 & -2 & -2 & -2 & -4 & 2 \\
\hline Netherlands & -4 & -4 & -6 & -4 & -4 & -6 & 4 & -5 & -3 & -4 \\
\hline France & 11 & 10 & 9 & 3 & 3 & 6 & 7 & 11 & 12 & 11 \\
\hline Finland & 11 & 11 & 11 & 9 & 7 & 7 & 8 & 8 & 6 & 6 \\
\hline United St. & 3 & 0 & 2 & 1 & 4 & 4 & 1 & -2 & 0 & 11 \\
\hline Spain & 8 & 6 & 7 & 5 & 7 & 6 & 1 & 7 & 6 & 11 \\
\hline Denmark & -5 & -6 & -4 & -4 & -8 & -1 & -4 & -6 & -9 & -10 \\
\hline Austria & -8 & -6 & -4 & -5 & -3 & -2 & 0 & -4 & -2 & -13 \\
\hline UK & 0 & -2 & 1 & 0 & -1 & -7 & -7 & -2 & -4 & -6 \\
\hline Belgium & 9 & 12 & 11 & 8 & 11 & 8 & 6 & 2 & 2 & 6 \\
\hline Luxembourg & -14 & -7 & -11 & -9 & -11 & -3 & -5 & -6 & -4 & -17 \\
\hline New Zealand & -5 & -4 & -3 & -7 & -5 & -9 & -15 & -10 & -9 & 10 \\
\hline Italy & 6 & 3 & 3 & 2 & 1 & 1 & 0 & -3 & -1 & 3 \\
\hline Germany & 3 & 3 & 3 & 1 & 0 & 1 & -1 & 1 & 2 & 2 \\
\hline Greece & 2 & 4 & 4 & 3 & 4 & 3 & 5 & 1 & 2 & 6 \\
\hline Korea Rep. & -4 & -4 & -5 & -7 & -10 & -12 & -10 & -10 & -12 & -3 \\
\hline Portugal & -9 & -8 & -7 & -9 & -5 & -5 & -4 & 2 & 2 & -1 \\
\hline Czech Rep. & -5 & 0 & 1 & 1 & 0 & 1 & 0 & 0 & -3 & -8 \\
\hline
\end{tabular}




\begin{tabular}{|c|c|c|c|c|c|c|c|c|c|c|}
\hline Hungary & -1 & -2 & -2 & -2 & -3 & -2 & 0 & 1 & -1 & -12 \\
\hline Poland & -1 & 2 & 1 & 3 & 4 & 3 & 3 & 1 & 2 & 0 \\
\hline Slovakia & 4 & 5 & 3 & 2 & 1 & 1 & 1 & 1 & 2 & 3 \\
\hline Mexico & -10 & -8 & -7 & -7 & -6 & -6 & -5 & -5 & -4 & -8 \\
\hline Turkey & -2 & -1 & -2 & -2 & -2 & -2 & -2 & 0 & 0 & 0 \\
\hline
\end{tabular}

Source: Authors' calculation.

On the other hand, the global economic crisis that appeared in 2019 has negatively affected the GDP per capita and employment indices of most developed economies. Both HDI and HDI-2 have decreased for all OECD countries except for Hungary. There has been a slight increase in its HDI-2. In our sample of 30 OECD countries. Spain has the highest unemployment rate at $11.3 \%$ in 2019 . In the same year, the Netherlands has the lowest unemployment rate at 2.8\%. Employment Index has decreased for Iceland, United States, United Kingdom, Spain, Italy, Luxembourg, and New Zealand whereas it has increased by $34.92 \%$ in Hungary that year.

Iceland, Luxembourg, and France lost (12), (10), and (5) ranks due to the global crisis whereas the ranks of New Zealand, Germany, Republic of Korea, and the United States have been increased by (16), (13), (12), and (9), respectively. The ranks of Norway, Australia, Netherlands, Mexico, and Turkey remained the same among the OECD countries with respect to the previous year although for instance the GDP per capita of developing OECD countries such as Turkey has been badly affected in 2019 after a prosperous year in 2018 (See Table 3).

Figure 3. Histogram of rank difference HDI-2 less HDI

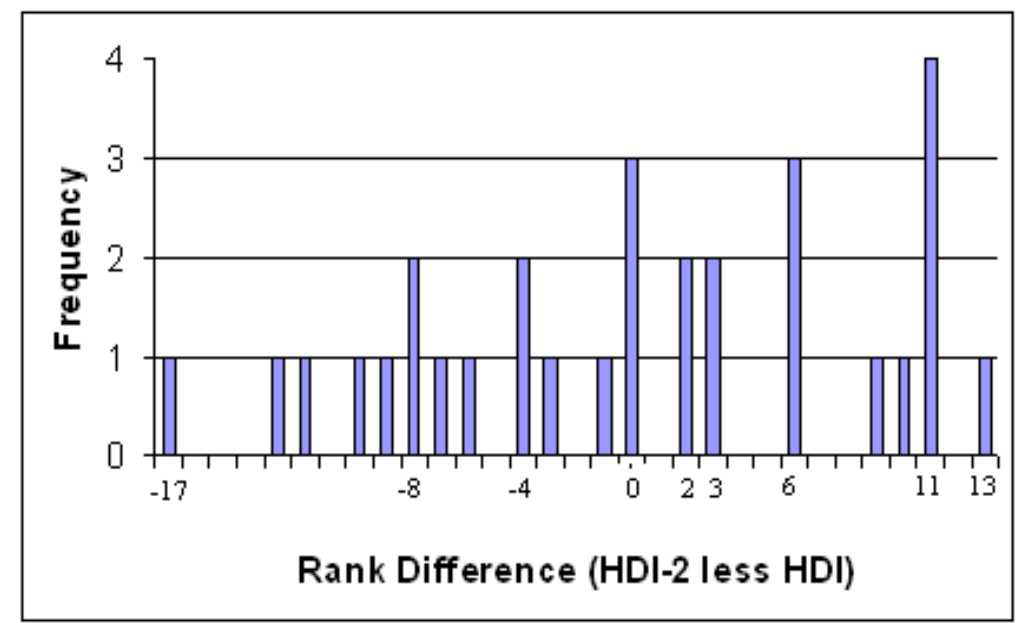

Source: Authors' calculation.

Unlike the rankings announced by UNDP, the rank of the United States drops by (2) in 2019 according to our proposed index. This is logical when the severeness of the crisis in the United States is noticed. Our analysis shows that HDI has underestimated the effects of the global crisis in Ireland, Greece, New Zealand, Finland, Australia, Sweden, France, Spain, and Belgium. Our analysis also further indicates that the economies of Switzerland, Iceland, Hungary, Luxembourg, Denmark, Austria, Canada, and the Netherlands have not been hit by the global crisis as severe as it has been alleged to have. 
Figure 4. Distribution of HDI and HDI-2 ranks in 2019

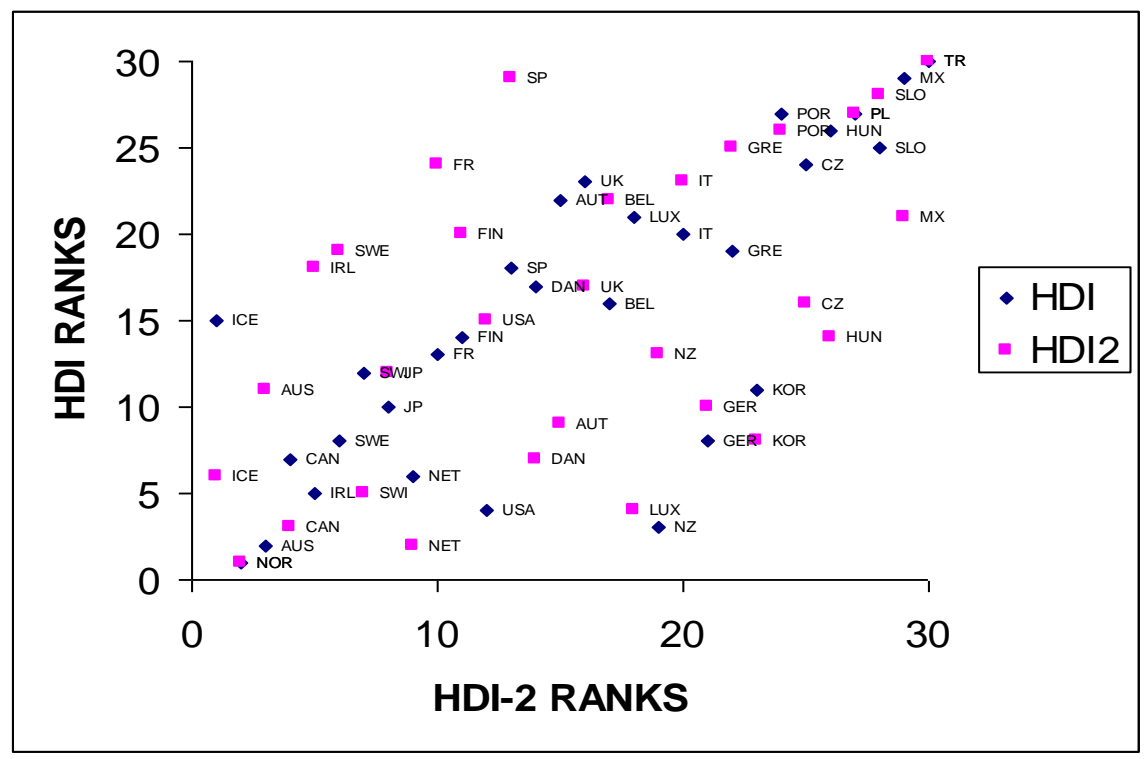

Source: Authors' calculation.

For 2019, we provide a histogram of rank changes between the HDI and our proposed HDI-2 in Figure 3, There is no change in rank in 3 countries, 14 countries show a positive change in rank (implying improved rank under HDI-2) while 13 countries show a negative change in rank (implying worsening of rank under HDI-2), 19 countries show a rank change that is greater than 5 in an absolute value. The mode of the absolute value of rank change is (11). In the top developed countries. the most substantial changes in rank were Luxembourg (17), Ireland (13), Austria (13), and Hungary (12). The most dramatic gainers were Luxembourg (17), Austria (13), Hungary (12), and Denmark (10). The maximum drop in ranks was by Ireland (13).

\section{Discussions}

The HDI is restrained to the range (0.1). The educational attainment and longevity indices do not show significant improvements in the short term. The HDI value may likely change only from year to year for any country by means of the improvements in GDP per capita. Therefore, the inclusion of employment as a dynamic measure that may significantly vary from year to year can bring additional explanatory power to the index (Mazumdar, 1999; Khan, 1991).

The original values and rankings in HDR-2019 are based on 169 countries worldwide. However, in this article, 30 OECD economies are taken as the research sample and re-ranked among themselves. It should be further noted that most economies in the sample are at the stage of very high development.

Development and especially human development, should not solely consist of economic growth. In fact, increasing each indicator's weight from $1 / 3$ to $1 / 4$ diminishes the effect of GDPI in HDI. We believe that lowering the weight by including more human and social factors would fit more to HDI's nature. Assuming that "growth is necessary but not sufficient condition for development" humanitarian aspects of the development process should be captured in its measurement and assessment attempts (Smith, 2009).

As shown in Table 1, the HDI-2 values are generally lower than those of HDI for each year. Moreover, they follow an increasing trend over the years. The year 2012 has been exceptional as HDI has decreased for Japan, France, the United States, Belgium, Luxembourg, Germany, Greece, Republic of Korea, Portugal, the Czech Republic, Hungary, Poland, Slovakia, Mexico, and Turkey. By means of this new method, the number of HDI determinants has slightly increased but it still remains at a manageable and easily understood size. Furthermore, such ramification in the calculation process 
enables us to define human development in a more holistic way. We understand that the process to attain high and very high development levels is more struggling than the current HDI envisaged.

The new HDI-2 values have shown that there is a need to attain better human development performance due to the problem of a global increase in unemployment. Therefore, this problem is reflected in the HDI measurements, and additional goals for human development are suggested. Without employment concern, the current HDI measures might direct the policymakers to emphasize heavily on the overall income factors, such as GDP, to increase human development. This is due to the non-income factors increasingly approached their limits, especially for highly developed countries. However, the distribution of income among people and the probability and chance of having a job should also be considered in evaluating nations' human development levels.

\section{Conclusions and Limitations}

This study can be considered as an initial attempt for the inclusion of the employment factor into HDI. Future studies may offer new and more advanced approaches for the usage of HDI in the assessment of development. Similarly, future research agenda may also concentrate on the computation of HDI by adding new indicators relevant to human development. Employment is a potentially usful indicator variable to be incorporated in a modified HDI index. Its inclusion into the HDI provides balance to the index. With improved explanatory power, the proposed version of HDI gives more information about the development performance of the nations. Furthermore, it is a relatively more advanced quantitative instrument to evaluate the HD capacity of the countries.

By adding a fourth sub-index to the current HDI, i.e the employment index. HDI has become more comprehensive with respect to development. The new HDI favors the countries attempting to overcome the unemployment problem. The effect of adding the employment dimension has resulted in more sensitive and realistic rankings between OECD countries. This study shows that the strong economies of Switzerland, Japan, South Korea, and Denmark have been underestimated by HDI. On the other hand, HDI has overestimated the economies of Australia, Ireland, Canada, Sweden, Germany, and Spain.

In short, including the employment factors to HDI as a new indicator has not only made the index broader but also presents a more suitable dimension for assessing the development performance of the countries. The integrity of HDI is also assured. Its concept is more complete and interpretable.

The major limitation of the proposed HDI has been the lack of data for all the countries. Future work will hopefully fill this gap and permit the development of a more comprehensive and reliable calculation of the HDI. Nevertheless, we believe that the current study provides non-negligible insights for a better understanding of the development process and implementation of public policies.

Author Contributions: All authors have contributed their best to complete this article. Conceptual initiators: D.L (20\%), methodological designer: P.P (25\%), compiling texts and affirmations for discussion: D.C.D (40\%), and data validation: M.D (15\%).

Funding: There is no specific (external grant) funding for this article.

Acknowledgments: We are very grateful to the Journal of Research in Emerging Markets for being the right "forum for discussion" from various researchers in the world to discuss economic issues relevant to current issues.

Conflicts of Interest: We declare that there are no conflicts of interest in this article and submit everything for the public.

\section{References}

Cherchye, L., Ooghe, E., \& Van Puyenbroeck, T. (2008). Robust human development rankings. Journal of Economic Inequality, 6(4), 287-321.

Chowdhury, S., \& Squire, L. (2006). Setting Weights for Aggregate Indices: An Application to the Commitment to Development Index and Human Development Index. Journal of Development Studies, 42(5), 761-771.

Clark, A. E., \& Oswald, A. J. (1994). Unhappiness and unemployment. Economic Journal, 104(424), 648-659. 
Crafts, N. F. (1997). The Human Development Index and changes in standards of living: Some historical comparisons. European Review of Economic History, 1(3), 299-322.

Crafts, N. (2002). The human development index, 1870-1999: Some revised estimates. European Review of Economic History, 6(3), 395-405.

Costantini, V., \& Monni, S. (2008). Sustainability and Human Development. Economia Politica, 25(1),11-31.

Darma, D. C. (2019). Determinants of the Gross Regional Domestic Product of East Kalimantan Province: Macroeconomic Variable Review. Review of Integrative Business and Economics Research, 9(1), 232-241.

Doessel, D. P., \& Gounder, R. (1994). Theory and measurement of living levels: Some empirical results for the human development index. Journal of International Development, 6(4), 415-435.

Engineer, M., King, I., \& Roy, N. (2008). The Human Development Index as a Criterion for Optimal Planning. The University of Melbourne, Department of Economics. Working Papers Series, No. 1041. Retrieved from http://www.economics.unimelb.edu.au/SITE/research/workingpapers/wp08/1041.pdf

Foster, J., Lopez-Calva, L., \& Szekely, M. (2005). Measuring the Distribution of Human Development: Methodology and an Application to Mexico. Journal of Human Development, 6(1), 5-29.

Fukuda-Parr, S. (2003). The Human Development Paradigm: Operationalizing Sen's Ideas On Capabilities. Feminist Economics, 9(2-3), 301-317.

Harkness, S. (2004). Social and Political Indicators of Human Well-Being. United Nations University: World Institute for Development Economics Research (WIDER). Research Paper No. 2004/33. Retrieved from https://www.wider.unu.edu/sites/default/files/rp2004-033.pdf

Harttgen, K., \& Klasen, S. (2010). A Household-Based Human Development Index. World Development, 40(5), 878899.

Hicks, D. A. (1997). The inequality-adjusted Human Development Index: A Constructive Proposal. World Development, 25(8), 1283-1298.

Hopkins, M. (1991). Human Development Revisited: A New UNDP Report. World Development, 19(10), 1469-1473.

Jean, S., \& Jiménez, M. (2011). The Unemployment Impact of Immigration in OECD countries. European Journal of Political Economy, 27(2), 241-256

Jean, S., Causa, O., Jimenez, M., \& Wanner, I. (2007). Migration in OECD countries: Labor market impact and integration issues. Organisation for Economic Co-operation and Development, Economics Department Working Papers, No. 562. Retrieved from https://www.oecd-ilibrary.org/economics/migration-in-oecdcountries_164604735126

Jordan, J. L. (2004). Constructing a Human Development Index for Georgia's Counties. University of Georgia, Department of Agricultural and Applied Economics Faculty Series No. 16672. Retrieved from http://purl.umn.edu/16672

Khan, H. (1991). Measure and determinants of socioeconomic development: A critical conspectus. Social Indicators Research, 24, 153-175.

Lüchters, G., \& Menkhoff, L. (2000). Chaotic Signals from HDI Measurement. Applied Economics Letters, 7(4), 267270.

Machin, S., \& Manning, A. (1999). Chapter 47 The causes and consequences of longterm unemployment in Europe. Handbook of Labor Economics, 3(C), 3085-3139

Mahlberg, B., \& Obersteiner, M. (2001). Remeasuring the HDI by data envelopment analysis. International Institute for Applied Systems Analysis (IIASA). Interim Report IR-01-069, Laxemburg, Austria. Retrieved from http://pure.iiasa.ac.at/id/eprint/6455/1/IR-01-069.pdf

Marchante, A. J., \& Ortega, B. (2006). Quality of Life and Economic Convergence across Spanish Regions, 1980 2001. Regional Studies, 40(5), 471-483.

Mazumdar, K. (1999). Measuring the Well-Beings of the Developing Countries: Achievement and Improvement Indices. Social and Industrial Research, 47, 1-60.

McGillivray, M. (1991). The Human Development Index: Yet Another Redundant Composite Development Indicator?. World Development, 19(10), 1461-1468.

Morse, S. (2003). Greening the United Nations' Human Development Index?. Sustainable Development, 11(4), 183198.

Neri, M. C. (2008). A Perceived Human Development Index. Ensaios Econômicos, No. 687. Retrieved from http://hdl.handle.net/10438/2173 
Nguefack-Tsague, G., Klasen, S., \& Zucchini, W. (2011). On weighing the components of the Human Development Index: A statistical justification. Journal of Human Development and Capabilities, 12(2), 183-202.

Ogwang, T. (2000). Inter-country inequality in human development indicators. Applied Economics Letters, 7(7), 443446.

Osberg, L., \& Sharpe, A. (2003). Human Well-being and Economic Well-being: What Values Are Implicit in Current Indices?. CSLS Research Report 2003-04. Retrieved from www.csls.ca/reports/10-03-02_wider.pdf

Panigrahi, R., \& Sivramkrishna, S. (2002). An adjusted Human Development Index: Robust country rankings with respect to the choice of fixed maximum and minimum indicator values. Journal of Human Development, 3(2), 301-311.

Paul, S. (1996). A modified human development index and international comparison. Applied Economics Letters, 3(10), 677-682.

Ristić, V. (1998). Gordana Matković (urednik): "lzveštaj o humanom razvoju Jugoslavija 1997. godine - Human Development Report Yugoslavia 1997. Stanovnistvo, 36(3-4), 141-148. Retrieved from https://www.idn.org.rs/ojs3/stanovnistvo/index.php/STNV/article/view/392

Segura, S. L., \& Moya, E. G. (2009). Human Development Index: A Non-Compensatory Assessment. Cuadernos de Economia, 28(50), 223-235.

Smith, P. (1993). Measuring human development. Asian Economic Journal, 7(1), 89-106.

Smith, R. B. (2009). Global human development: Accounting for its regional disparities. Quality and Quantity, 43(1), 1-34.

Srinivasan, T. N. (1994). Human development: a new paradigm or reinvention of the wheel?. The American Economic Review, 84(2), 238-243.

Stapleton, L. M., \& Garrod, G. D. (2007). Keeping things simple: why the Human Development Index should not diverge from its equal weights assumption. An International and Interdisciplinary Journal for Quality-of-Life Measurement, 84(2), 179-188.

Taner, M. T., Sezen, B., Alpkan, L., \& Aren, S. (2010). Recomputation of UNDP's HDI rankings by Data Envelopment Analysis. Emerging Markets Journal, 1(2), 21-35.

The Human Development Report. (2020). United Nations Development Program. Oxford University Press: New York.

Ul Haq, M. (1995). Reflections on Human Development. New York: Oxford University Press.

Wijaya, A., Kasuma, J., Tasențe, T., \& Darma, D. C. (2021). Labor force and economic growth based on demographic pressures, happiness, and human development: Empirical from Romania. Journal of Eastern European and Central Asian Research, 8(1), 40-50.

Wijayanti, T. C., \& Darma, D. C. (2019). The Role Of Investment And Government Expenditure On Grdp And Human Development In East Kalimantan. International Journal of Scientıfic E Technology Research, 8(9), 12321237.

Wolff, H., Chong H., \& Auffhammer, M. (2009). Human Development Index: Are Developing Countries Misclassified?. Agricultural \& Applied Economics Association 2009, AAEAEACCI Joint Annual Meeting. Retrieved from https://www.researchgate.net/publication/228583433_Human_Development_Index_Are_Developing_Cou ntries_Misclassified\#: :text=First\%2C\%20using\%20the\%20cutoff\%20values,of\%20developing\%20countries $\% 20$ are $\% 20$ misclassified.

(C) 2020 by the authors. This article is an open-access article distributed under the terms and conditions of the Creative Commons Attribution (CC BY) license (http://creativecommons.org/licenses/by/4.0/). 